\title{
$\beta 1$-integrins signaling and mammary tumor progression in transgenic mouse models: implications for human breast cancer
}

\author{
Hicham Lahlou and William J Muller*
}

\begin{abstract}
Consistent with their essential role in cell adhesion to the extracellular matrix, integrins and their associated signaling pathways have been shown to be involved in cell proliferation, migration, invasion and survival, processes required in both tumorigenesis and metastasis. $\beta 1$-integrins represent the predominantly expressed integrins in mammary epithelial cells and have been proven crucial for mammary gland development and differentiation. Here we provide an overview of the studies that have used transgenic mouse models of mammary tumorigenesis to establish $\beta 1$-integrin as a critical mediator of breast cancer progression and thereby as a potential therapeutic target for the development of new anticancer strategies.
\end{abstract}

\section{Introduction}

Breast cancer continues to be the most common cancer diagnosed and the leading cause of cancer-related death in women worldwide. In North America it has been estimated that one woman out of nine will be diagnosed with breast cancer in her lifetime and that one in four among them will die from the disease [1]. As with other cancers, the combination of genetic and epigenetic alterations is fundamental in the genesis of breast cancer [2]. As the result of multiple alterations, mammary cancer progresses through multiple stages in a multistep process that drives normal breast cells into highly malignant cells. The resulting tumor cells can then invade through surrounding tissues and metastasize to distal organs, particularly to bones, brain, liver, and lungs [3].

*Correspondence: william.muller@mcgill.ca

Goodman Cancer Centre, McGill University, 1160 Pine Avenue West, Montreal, Québec, Canada H3A 1A3
The majority of breast cancers are carcinomas of ductal origin since they arise from epithelial cells lining the mammary ducts. The pathogenesis involves an initial benign intraductal hyperplasia, which progresses through cellular atypia (atypical hyperplasia) and occlusion of the duct (ductal carcinoma in situ). This later step can be followed by locally invasive carcinoma and subsequent metastasis to secondary sites [4]. The acquired invasive properties include enhanced migratory behavior and the capacity of the tumor cells to breach the mammary basement membrane (BM), the dense matrix surrounding tumors and the blood vessel walls [5]. All of these processes involve dynamic adhesion of the tumor cell to extracellular matrices (ECMs) through integrins, a major family of $\alpha / \beta$ heterodimeric cell surface receptors [6].

The integrin family contains, in mammals, $18 \alpha-$ subunits and eight $\beta$-subunits that form 24 distinct receptors with specific tissue distribution and that appear to have specific and nonredundant functions as shown by their specificity for ECM ligands and knockout mouse phenotypes [7]. The primary function of the integrin family is to mediate cell-cell and cell-matrix adhesion. Furthermore, the binding of ECM components such as fibronectin, laminin, proteoglycans and collagen to integrins leads to the recruitment of numerous adaptor and signaling proteins to the cytoplasmic tails of the integrin $\beta$-subunits, forming adhesion protein complexes [8] that initiate signaling cascades promoting cell polarity, motility, differentiation, proliferation and survival [9]. Accordingly, when overexpressed in tumor cells, integrins contribute to cancer progression and metastasis by increasing tumor cell migration, invasion, proliferation and survival as well as tumor angiogenesis $[6,10]$.

Integrin heterodimers are present on the cell surface in different conformations that vary in their affinity for ligands depending on the nature of both the extracellular and the intracellular stimuli $[11,12]$. Indeed, integrins not only send signals to the cell in response to extracellular guidance cues, such as chemokines or growth factors - a process called "outside-in" signaling [12] - but they also respond to intracellular signals and alter the way they 
interact with the extracellular environment [13]. These intracellular signals can regulate integrin receptor adhesiveness by modulating the conformations and the degree of binding to ECM ligands, regulating, for instance, cell migration and growth [11]. This is generally referred to as "inside-out" signaling and notably involves crosstalk between receptor tyrosine kinase or G-proteincoupled receptor signaling pathways and integrins $[14,15]$ . Another significant level of regulation of cell adhesion and migration on ECM protein ligands involves the modulation of integrin endocytosis and recycling to the plasma membrane [16].

In the present review we will focus on $\beta 1$-integrins, which constitute the largest subgroup of integrins, since the $\beta 1$-subunit can form heterodimers with the most different $\alpha$-subunits (at least 12). After a description of its role in normal mammary gland development and its status in the pathological gland, we will emphasize the contribution of transgenic mouse models in highlighting how crucial $\beta 1$-integrin appears to be for breast cancer progression.

\section{$\beta 1$-integrin signaling and mammary gland development}

Whereas many subunits occur in only a single integrin heterodimer, the $\beta 1$-subunit is found in 12 different integrins (Figure 1) that all bind to ECM protein ligands, namely collagen, laminin, fibronectin, tenascin $\mathrm{C}$ and vitronectin $[17,18]$. $\beta 1$-integrins are expressed in a wide variety of tissues and different cell types throughout the body. They are critical in the induction and maintenance of cell differentiation and are involved in various physiological functions and in tissue homeostasis [17]. $\beta 1$ integrin has thus been shown critical for cartilage and bone formation [19], skeletal muscle development [20,21], epidermis formation [22], development of the cerebral cortex [23] and angiogenesis [24]. Accordingly, knockout studies have revealed an essential role for $\beta 1$-integrin in early development, its genetic deletion resulting in embryonic lethality shortly after implantation, between embryonic days 6.5 and 7.5 [25-27].

\section{$\beta 1$-integrin signaling: a crucial role for the focal adhesion kinase axis}

$\beta 1$-integrin has been shown to bind directly or indirectly via its cytoplasmic domain to a substantial number of proteins $[8,28]$. Since integrins lack enzymatic activity and an actin binding domain, they must bind to partners that will support cytoskeleton remodeling and activation of downstream signaling cascades pathways involved in, for example, cell proliferation. Some of these proteins, like talin, kindlins, filamin, $\alpha$-actinin, tensin, integrin cytoplasmic domain-associated protein-1, integrin-linked kinase, $14-3-3 \beta$ and CD98, couple $\beta 1$-integrins to the

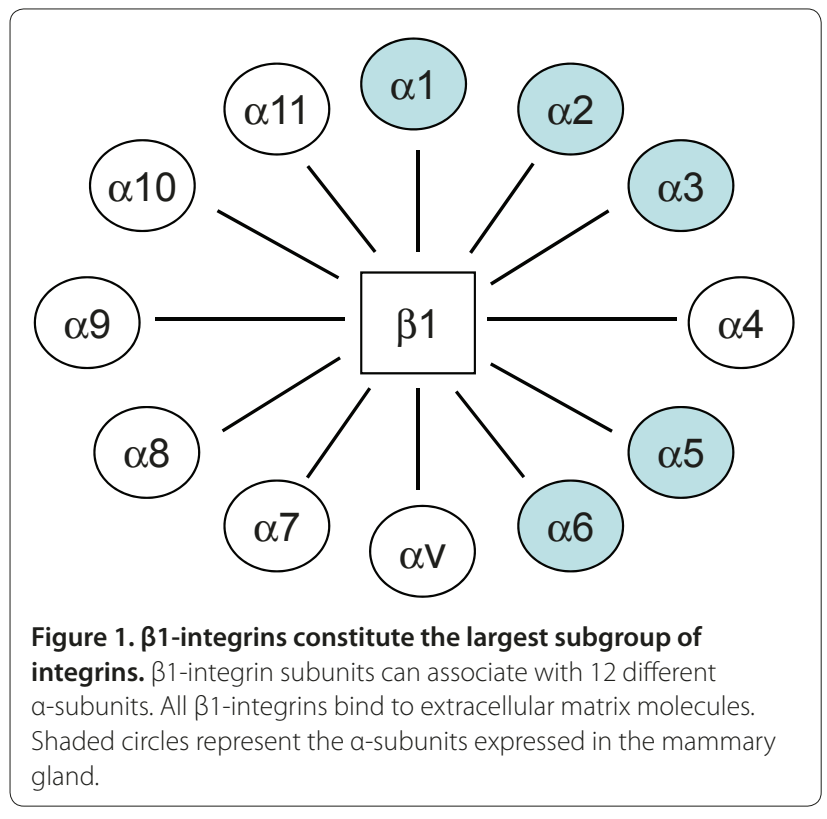

actin cytoskeleton and/or are involved in $\beta 1$-integrinmediated cell adhesion and motility. Others, such as focal adhesion kinase (FAK), paxillin, receptor of activated kinase-1 or the Src family kinases yes and lyn, function as scaffolding and/or catalytic adaptors that allow activation of signaling pathways from adhesion sites to intracellular effectors [28-30].

Interestingly, some of these integrin-associated adaptors such as FAK, which is considered a central player in integrin-mediated signaling [31], show a crossover functionality. Integrin clustering elicits FAK activation and localization to focal adhesions. Two NXXY motifs present in the $\mathrm{C}$-terminal of $\beta 1$-integrin have been shown to be critical to its ability to recruit FAK and induce its autophosphorylation on Y397 [32]. FAK can then contribute to integrin signaling in different ways. As a tyrosine kinase, FAK phosphorylates substrates such as paxillin, a multidomain adaptor that can also be directly bound to $\beta 1$-integrin [33]. However, paxillin can only become phosphorylated by FAK when it associates with the kinase through an interaction between its LD motifs and FAK's carboxy terminal focal adhesion targeting domain $[34,35]$.

Another role of FAK lies in its ability to form interactions with other signaling molecules and thus to act as a scaffold protein recruiting several adaptors to focal adhesion sites [31]. Indeed, FAK autophosphorylation at Y397 promotes recruitment of c-Src, which in turn can phosphorylate FAK on various tyrosine residues that act as docking sites for a number of $\mathrm{SH} 2$ domain-containing signaling adaptors, facilitating the activation of a diverse range of signaling pathways [36,37]. For instance, Grb2 binding to phosphorylated Y925 activates a signaling 
pathway to ERK regulating vascular endothelial growth factor expression [38], and p85-PI3K regulatory subunit binding to the initially phosphorylated Y397 induces AKT activation and promotes cell survival [39]. FAK also contains proline-rich domains that mediate interactions with SH3 domain-containing proteins such as the multiadaptor Crk-associated substrate (p130Cas) or the GTPase regulator associated with FAK. Once phosphorylated by FAK-recruited c-Src, p130CAS is essential, for example, to recruit the Crk-Dock180 complex and activate Rac, thereby inducing migration [40] or the activation of a Ras/Rac/Pak1/JNK survival pathway [41].

\section{$\beta 1$-integrin in the mammary gland}

In the normal mammary gland, interaction between epithelial cells and with the underlying BM is required for structural and functional integrity of the ductal component of the gland. The breast ductal architecture is indeed comprised of a bilayer of luminal epithelial and basal myoepithelial cells, which remain separated from the stroma by the BM. The myoepithelial layer limits contact between luminal cells and the BM. In the alveoli (the milk-secreting units), however, luminal cells can directly interact with the BM between the processes of the stretched myoepithelial cells [18]. Integrins are predominantly expressed in the basal cell layer of the mammary epithelium in comparison with the luminal compartment. Owing to their direct interactions with ECM ligands, $\beta 1$-integrins play a critical role in the maintenance of mammary tissue integrity [18]. In addition, they are essential for the control of cell survival and proliferation during mammary gland development as well as for mammary epithelial cell differentiation [4244]. Moreover, $\beta 1$-integrin expression has been revealed as necessary for maintenance of functional mammary stem cells, which are part of the basal compartment, allowing mammary morphogenesis and segregation of the two mammary ductal compartments [45,46]. Integrins expressed on breast epithelial cells include $\beta 1$ integrin-containing and $\beta 4$-integrin-containing heterodimers (Figure 2) $[18,45,47]$. $\alpha 6 \beta 4$-integrin has a role in maintaining epithelial integrity based on its ability to mediate formation of hemidesmosomes that link the intermediate cytokeratin filament network of the mammary cells to ECM laminins [48].

Mammary $\beta 1$-integrins, consisting of $\alpha 1 \beta 1, \alpha 2 \beta 1, \alpha 3 \beta 1$, $\alpha 5 \beta 1$ and $\alpha 6 \beta 1$, present a more heterogeneous localization and role. They are present at sites of cell-ECM interaction both on myoepithelial cells and alveolar luminal cells. Luminal epithelial cells also express the $\alpha 2 \beta 1, \alpha 3 \beta 1$, and $\alpha 6 \beta 1$ heterodimers at cell-cell junctions, however, while $\alpha 1 \beta 1$ and $\alpha 5 \beta 1$ seem to be exclusively expressed in the myoepithelium (Figure 2) [18]. Although highest expression of the $\alpha 5 \beta 1$-integrin was found in myoepithelial

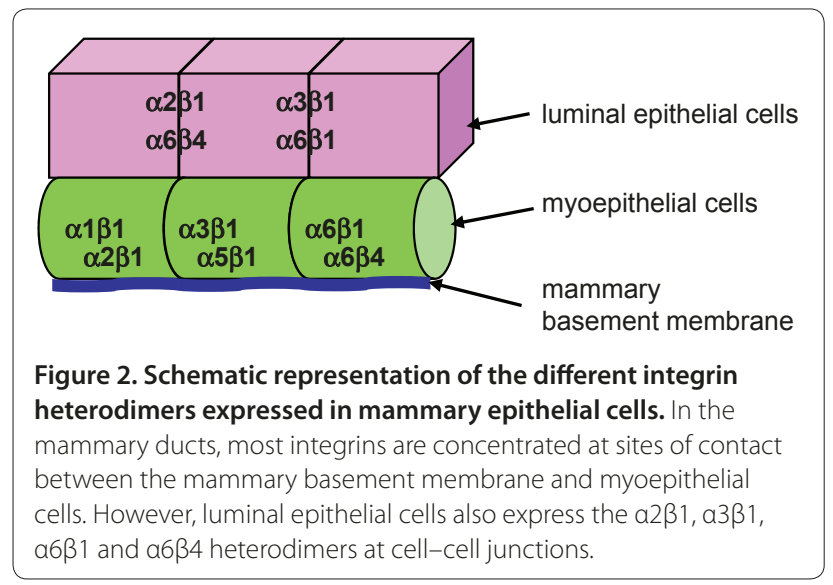

cells, luminal cells in contact with the BM can also stain strongly for $\alpha 5 \beta 1$ [49]. An in vitro study suggests that $\beta 1$ integrins can have a significant impact on hormonal control of mammary development by controlling, for example, expression of estrogen receptor $\alpha$ [50]. Reciprocally, ovarian steroids like estrogen and progesterone have been shown in vivo to regulate mammary gland expression of $\alpha 5 \beta 1$-integrin during puberty and sexual maturation [49].

In vivo evidence for a role of these integrins in mammary gland development came from studies using a gene deletion approach. Murine mammary glands formed from either $\alpha 1$-integrin-null, $\alpha 3$-integrin-null, $\alpha 6$-integrin-null or $\beta 4$-integrin-null epithelia are thus fully developed and functional $[51,52]$. The only integrin subunits so far shown to be indispensible for appropriate mammary gland development are $\alpha 2$ and $\beta 1[43,44,53]$. Although fertile and capable of lactating, mice deficient in $\alpha 2$-integrin show a marked decrease in mammary ductal branching [53]. The conditional deletion of $\beta 1$ integrin using targeted $\mathrm{Cre}$ recombinase expression in the luminal cell population after pubertal development and during later stages of differentiation (i.e., pregnancy and/or lactation) using $\beta$-lactoglobulin and whey acidic protein promoters, respectively, affects alveologenesis and lactation due to an inhibition of mammary epithelial cell proliferation and differentiation [43,44]. Moreover, the ablation of $\beta 1$-integrin from the basal cell layer of the mammary epithelium using Cre under control of the keratin 5 promoter impairs ductal branching as well as lobuloalveolar morphogenesis in pregnancy, presumably because of disruption of the basal cell interactions with the ECM and disruption of stem cell renewal [46]. It is worth noting that in a model using the mouse mammary tumor virus (MMTV) promoter-driven Cre recombinase, where Cre is exclusively expressed in mammary luminal epithelial cells from 3 weeks of age [46,54], ablation of $\beta 1$-integrin expression does not interfere with the initial stages of mammary ductal outgrowth [55]. 


\section{$\beta 1$-containing integrin receptors are involved in human breast cancer progression}

In the early 1990 s several studies using human breast cancer samples revealed an aberrant expression of $\beta 1$ integrin. Either assayed by immunohistochemistry on frozen sections [56-59] or by in situ hybridization techniques [60], $\beta 1$-integrin expression has been found to be generally heterogeneous but also altered in 30 to $50 \%$ of breast cancers. This observation was confirmed in later investigations $[61,62]$. Many of these studies scored $\beta 1$ integrin expression based on a comparison with staining seen in normal tissues (i.e., concentrated at the BM, in the myoepithelial layer), and therefore possibly inaccurately reported a decrease of or a loss of expression [56, $58,62]$. Indeed, in invasive carcinomas this cell layer is most often absent and the expression of integrins on the surface of carcinoma cells is diffuse. This expression pattern may thus have led to the erroneous assumption that there is an overall decrease in $\beta 1$-integrin [47]. From numerous in vitro studies using human breast cancer cell lines, however, it is obvious that $\beta 1$-integrin is not only expressed but is required for proliferation, survival and invasiveness of the transformed cells [63-65]. Nevertheless, in this context, whether the regulation of $\beta 1$-integrin overexpression is transcriptional, translational or posttranslational is not known.

In the same way, studies to associate $\beta 1$-integrin expression in breast cancer with patient survival gave contradictory conclusions. While a trend was seen towards poorer survival of patients with tumors with absent or weak expression of $\beta 1$-integrin in a study of 55 cases [62], a lack of any difference in the survival curves for presence or absence of staining for $\beta 1$-integrin was reported in another study involving 99 patients [61]. More recently, Yao and colleagues reported that an increased $\beta 1$ integrin level, which was also linked to the level of its ligand fibronectin, was associated with significantly decreased 10-year overall survival and recurrence-free survival in a cohort of 149 patients with early-stage invasive breast cancer [66]. Interestingly, neither estrogen receptor expression nor progesterone receptor expression was significant with respect to $\beta 1$-integrin overexpression or overall or disease-free survival [66]. In agreement with this, Lesniak and colleagues did not find any significant correlation between $\beta 1$-integrin expression and prognostic factors such as estrogen receptor and progesterone receptor in a study involving 113 patients with human epidermal growth factor receptor 2 (HER2)-positive metastatic breast cancer [67]. In contrast, a strong significant association was found between $\beta 1$-integrin overexpression and short time to tumor progression in women treated with trastuzumab-based chemotherapy [67].

Studies reporting activation and elevated expression of $\beta 1$-integrin signaling effectors in human breast cancers strengthen a potential role of this integrin as a prognostic marker. A large proportion of primary human breast cancers possess elevated FAK expression that is further correlated with malignant transformation and poor clinical outcome $[68,69]$. Paxillin expression was found to be correlated with HER2 overexpression in an immunohistochemistry study of 314 primary invasive breast carcinomas [70], and BCAR1/p130Cas protein levels were found to be inversely related with relapse-free survival and overall survival as assessed by ELISA on 2,593 primary breast tumor cytosols [71].

\section{Genetic ablation of $\beta 1$-integrin in transgenic mice reveals a critical role in mammary tumor initiation, metastasis and dormancy}

Despite an ostensible role for $\beta 1$-integrin in mammary gland development, the involvement of this particular integrin in breast cancer initiation and progression has only recently been demonstrated. This has been permitted by the use of engineered murine models of human breast cancers where $\beta 1$-integrin expression has been specifically disrupted in the mammary luminal epithelium.

\section{$\beta 1$-integrin in PyVmT-induced tumorigenesis}

The first study directly underlining an in vivo role for $\beta 1$ integrin in mammary tumorigenesis was performed using the polyoma virus middle $\mathrm{T}$ antigen $(\mathrm{PyVmT})$ mouse model of breast cancer [55]. A conditional $\beta 1$ integrin allele (that is, LoxP1 flanked) was introduced into transgenic mice expressing the PyVmT oncogene and Cre both under the control of the MMTV promoter/ enhancer [55]. The PyVmT mouse model of breast cancer is extensively used to study mammary tumorigenesis. This model recapitulates the stages of human disease since it evolves through four distinctly identifiable stages of tumor progression, from premalignant to invasive [72]. Aside from exhibiting a rapid onset and a high rate of metastasis to the lung, the MMTV-PyVmT mammary tumor model presents the advantage of reflecting the downstream signaling pathways triggered by the HER2 oncogene involving activation of critical cancer-related molecules such as c-Src, the p85-PI3K regulatory subunit or Ras [73].

Using targeted excision of $\beta 1$-integrin in luminal epithelial cells where the PyVmT oncogene was expressed [55], we have shown that $\beta 1$-integrin was absolutely required for the induction of mammary tumors. Indeed, all tumors that arose in the MMTV-Cre/MMTVPyVmt; $\beta 1$ LoxP1 animals were populated by cells retaining expression of $\beta 1$-integrin and lacking Cre expression. This was proposed to be the result of a selective pressure against MMTV-Cre expression in mammary luminal epithelial cells undergoing PyVmT-driven transformation [55]. In addition, in vitro data using primary cultured 
MMTV-PyVmt; $\beta 1$ LoxP1 tumor cells infected with Creexpressing adenoviruses have shown that ablation of $\beta 1$ integrin in mammary tumor cells is associated with a proliferative block and a disruption in FAK activation and subcellular localization [55]. Interestingly, although PyVmT tumor cells lacking $\beta 1$-integrin were unable to proliferate, they failed to exhibit any evidence of apoptotic cell death. In fact, viable quiescent tumor cells lacking $\beta 1$-integrin could be detected even 8 weeks after transplantation into cleared mammary fat pads of syngeneic recipient mice. The presence of $\beta 1$-integrinnull tumor cells that are unable to proliferate but still retain viability exhibits a striking resemblance to the phenomenon of tumor dormancy [55,74]. Overall, this work has provided evidence that $\beta 1$-integrin expression is required for the initial stages as well as for the maintenance of advanced stages of PyVmT-induced mammary tumorigenesis.

Consistent with these analyses, four independent studies evaluating the loss of function of the $\beta 1$-integrin signaling partner FAK in the MMTV-PyVmT mouse model have demonstrated a critical role for this kinase in initiation and/or progression of mammary tumorigenesis [54,7577]. At first, using an approach identical to the aforementioned, mammary epithelial disruption of FAK was demonstrated to result in a dramatic reduction in the proliferative potential of PyVmT-transformed cells without exhibiting evidence of enhanced apoptosis. Importantly, these results demonstrate that although FAK is dispensable for the initiation of mammary tumorigenesis, it is still required for the transition of premalignant hyperplasias to carcinomas and their subsequent metastases [54]. This dramatic result was subsequently confirmed by a number of independent laboratories [75-77]. One of these studies suggested that the block in PyVmT tumor progression was due to the reduction of the pool of cancer stem/progenitor cells [75]. Collectively, these studies argue that FAK plays a critical role in PyVmTmediated tumorigenesis and support the in vivo data establishing $\beta 1$-integrin as a crucial player in mammary tumor progression.

\section{$\beta 1$-integrin in ErbB2-induced tumorigenesis}

Amplification and overexpression of ErbB2/HER2, a member of the epidermal growth factor receptor (EGFR) family, is observed in 25 to $30 \%$ of sporadic breast cancers and is inversely correlated with the survival of the patient [78]. Direct evidence indicating that ErbB2 acts as a mammary oncogene derives from initial studies of transgenic mice expressing an activated $\mathrm{Neu}$ (the rat homolog of ErbB2) under the transcriptional control of the MMTV promoter [79].

Recently, in the context of this mouse model, the role of $\beta 1$-integrin in ErbB2-induced mammary tumor progression was investigated by utilizing the same conditional $\beta 1$-integrin strain we previously crossed to the PyVmT model of breast cancer [55]. One complication encountered with the MMTV-Cre mouse line we initially used is the stochastic expression of the Cre transgene ranging from 50 to $80 \%$ of the luminal epithelial cells. Moreover, we estimated the overall proportion of Cre nonexpressing cells at approximately one-third $[54,55]$. Cre-negative mammary epithelial cells thus retain expression of the conditional allele and are selectively targeted for oncogenic transformation $[54,55]$. To circumvent the selective pressure against the Crepositive/ $\beta 1$-negative cells undergoing transformation, we have crossed the conditional $\beta 1$-integrin strain to the MMTV-NIC strain [80,81]. These mice coexpress both an activated ErbB2 and the Cre recombinase from the same bicistronic transcript due to the presence of an internal ribosome entry site between the two cDNA sequences [80,81]. Expression of activated ErbB2 and Cre is hence coupled within the luminal epithelial cell, precluding the possibility of obtaining ErbB2 oncogeneexpressing/Cre-negative "escapee" transformed cells. In contrast to the complete block in PyVmT-induced tumorigenesis [55], mammary epithelial disruption of $\beta 1$ integrin did not prevent ErbB2-mediated tumor induction [80]. Although a significant 33-day delay in tumor onset was observed, all of the mice developed mammary tumors histologically similar to their control counterparts [80]. Nevertheless, quantification of both the penetrance and the extent of lung metastasis in the $\beta 1$-integrindeficient mice revealed that loss of this integrin was associated with a twofold reduction in the number of mice that developed metastases and with a sixfold reduction in the average metastatic burden compared with $\beta 1$-integrin-proficient controls. Therefore, although $\beta 1$-integrin is not required for ErbB2-mediated mammary tumor initiation and progression, it does play a major role in the subsequent metastatic phase of tumorigenesis in the MMTV-Neu-NDL2-5 model [80].

Interestingly, examination of the $\beta 1$-integrin-deficient mammary tumors revealed a reduction in both tumor cell survival and angiogenic infiltration. This later effect has been shown to be cell autonomous, as demonstrated by transplantation into the fat pads of immunodeficient mice and quantification of CD31-positive vessels [80]. Moreover, analysis of the activation state of numerous integrin-coupled signaling partners using phosphotyrosine-specific antibodies indicated that $\beta 1$-integrindeficient tumors exhibited a decrease in c-Src, FAK, p130Cas and paxillin phosphorylation, possibly indicating a defect in adhesion responsible for the reduced metastatic potential of Neu mammary tumor cells lacking $\beta 1$-integrin [80]. Another striking molecular effect of $\beta 1$ integrin deletion was a remarkable decrease in EGFR 
tyrosine phosphorylation in the $\beta 1$-integrin-deficient tumors when compared with control samples [80]. Indeed, an important function of $\beta 1$-integrin signaling is its capacity to transphosphorylate EGFR and to cooperate with this receptor in the control of cell proliferation, adhesion and migration [82]. $\beta 1$-integrin-EGFR crosstalk and transactivation have also been implicated in the endocytic recycling of these two receptors. Particularly, the enhanced migration of human ovarian carcinoma cells has been shown to involve Rab-coupling proteindependent recycling of $\alpha 5 \beta 1$-integrin and coordination of its trafficking with that of EGFR [83]. Furthermore, $\alpha 5 \beta 1$-integrin-EGFR interaction has been reported to contribute to the invasive phenotype of human prostate cancer cells through the formation of a urokinase-type plasminogen activator receptor/ $\alpha 5 \beta 1$-integrin/EGFR ternary complex [84]. The profound defect in metastasis observed in $\beta 1$-integrin-deficient MMTV-Neu mice may thus be the result of altered recycling of EGFR and/or disruption of EGFR-coupled signaling pathways involved in cell invasion.

Finally, analyses revealed that the $\alpha 6$-integrin and $\beta 4$ integrin subunits were downregulated upon disruption of $\beta 1$-integrin [80]. $\alpha 6 \beta 4$-integrin has been associated with reduced survival and poor prognosis in breast cancer [85]. Moreover, in vitro its activation has been implicated in breast carcinoma progression [86]. Interestingly, antibody-mediated crosslinking of $\alpha 6 \beta 4$-integrin has been shown to induce breast carcinoma cell-surface clustering of EGFR and to promote Rho activation in response to EGF, suggesting that $\alpha 6 \beta 4$-integrin-EGFR crosstalk may facilitate tumor cell cytoskeletal rearrangements important for tumor progression [87]. Therefore, together with the reduced phosphorylation of several $\beta 1$ integrin signaling partners, downregulation of both $\alpha 6 \beta 4$-integrin and EGFR presumably plays a decisive role in the impaired metastatic capacity of the $\beta 1$-integrindeleted mammary tumor cells. Moreover, the $\beta 4$-integrin downregulation observed consequently to $\beta 1$-integrin conditional knockout is in agreement with in vivo analyses obtained on a MMTV-activated-Neu strain [88]. By introducing a targeted deletion of the $\beta 4$-integrin signaling domain into a mouse model of ErbB2-induced mammary carcinoma, Guo and colleagues have shown that $\beta 4$-integrin signaling is also critical for Neu-induced tumor progression [88]. In fact, the $\beta 4$-integrin mutant transgenic mice presented phenotypes very similar to the conditional $\beta 1$-integrin strain we developed. Loss of $\beta 4$ integrin signaling inhibits mammary tumor onset and initial growth by decreasing cell proliferation and increasing apoptotic rates, and inhibits tumor invasion and metastasis to the lungs [88]. Overall, unlike the PyVmT model in which $\beta 1$-integrin is required for tumor initiation, $\beta 1$-integrin seems to be primarily involved in the metastatic phase of tumor progression in the context of ErbB2-induced transformation.

It is interesting to note that targeted disruption of the $\beta 1$-integrin effector integrin-linked kinase in the same ErbB2 mouse model was recently demonstrated to be associated with complete loss of p130Cas and paxillin tyrosine phosphorylation, and with impaired Neuinduced tumor progression [89]. Moreover, by crossing MMTV-p130Cas and MMTV-Neu mice, Cabodi and colleagues generated double-transgenic mice with an accelerated onset of mammary tumor formation. The subsequent tumors exhibited increased activation of Src and Akt pathways, suggesting a role for the p130Cas adaptor as a positive regulator of both cell proliferation and cell survival induced by the Neu proto-oncogene [90]. These data further argue that $\beta 1$-integrin - as opposed to $\beta 3$-integrin and $\beta 5$-integrin, which have been shown to be dispensable for Neu-induced tumor growth [91] - favors ErbB2-mediated tumor progression.

\section{$\beta 1$-integrin as a potential therapeutic target}

Given the accumulation of in vivo evidence, it is tempting to claim that $\beta 1$-integrin shows interesting therapeutic potential as a target for the treatment of human breast cancer. However, as pointed out earlier, because of conflicting studies $[61,62,66]$, expression of the $\beta 1$ subunit alone cannot be clearly accepted as a useful prognostic indicator in patients with breast cancer. Although inhibitory antibodies directed against $\beta 1$ integrin (notably clone AIIB2) have already been shown to be effective in reverting the tumorigenic phenotype of breast cancer cell lines $[64,65]$, strategies to target the $\beta 1$ integrin subunit for therapy (Table 1) have not progressed rapidly, presumably because of the heterogeneity of the $\beta 1$ subgroup of integrins. Indeed, the $\beta 1$-subunit can form heterodimers with at least 12 different $\alpha$-subunits (Figure 1). In mammary ducts, this $\beta 1$-subunit is found in heterodimers with $\alpha 1, \alpha 2, \alpha 3, \alpha 5$ and $\alpha 6$, hence mediating adhesion to a number of different ECM ligands including collagen, laminin and fibronectin [18].

A recently published work was the first to define a specific role for a single $\alpha \beta 1$ heterodimer in mammary tumor progression [92]. To do so, the authors crossed $\alpha 2$ integrin-null transgenic animals [53] with MMTV-Neu mice to generate animals expressing an oncogenic ErbB2 in $\alpha 2 \beta 1$-integrin-deficient mammary epithelium [92]. Since $\alpha 2 \beta 1$-integrin has been shown to mediate hepatic metastasis [93], it was surprising to observe that loss of the $\alpha 2 \beta 1$-integrin not only (even modestly) reduces mammary tumor latency in MMTV-Neu mice but markedly increases metastasis to the lungs [92]. Although a role for $\alpha 2 \beta 1$-integrin in the tumor microenvironment cannot be excluded in this model, in vitro experiments performed on primary cultured epithelial tumor cells 
Table 1. $\beta 1$-integrin inhibitors currently in preclinical or clinical development for cancer therapy

\begin{tabular}{|c|c|c|c|c|c|}
\hline Drug or treatment & $\begin{array}{l}\text { Type of } \\
\text { therapeutic agent }\end{array}$ & Stage & Target & Tumor model & Reference \\
\hline Clone AllB2 & Rat $\lg \mathrm{G}_{1} \mathrm{mAb}$ & Preclinical & $\beta 1$-subunit & MCF-7 human breast cancer xenograft & [64] \\
\hline $\begin{array}{l}\text { Clone AllB2 + ionizing } \\
\text { radiation }\end{array}$ & $\begin{array}{l}\text { Rat lgG, } m A b+ \\
\text { radiotherapy }\end{array}$ & Preclinical & $\beta 1$-subunit & MCF-7 human breast cancer xenograft & {$[102]$} \\
\hline Clone 339.1 & Rat lg $G_{1} m A b$ & Preclinical & $a 5 \beta 1$ & $\begin{array}{l}\text { SVR murine angiosarcoma and A673 human } \\
\text { rhabdomyosarcoma xenografts }\end{array}$ & [95] \\
\hline \multirow[t]{3}{*}{ Volociximab } & $\begin{array}{l}\text { Chimeric ( } 82 \% \text { human/ } \\
18 \% \text { murine) } \operatorname{lgg}_{4} \mathrm{mAb}\end{array}$ & Preclinical & $a 5 \beta 1$ & Rabbit VX2 carcinoma model & [97] \\
\hline & & Phase I & $a 5 \beta 1$ & Patients with advanced solid malignancies & {$[105]$} \\
\hline & & Phase II & $a 5 \beta 1$ & $\begin{array}{l}\text { Patients with platinum-resistant advanced } \\
\text { epithelial ovarian cancer or primary peritoneal cancer }\end{array}$ & [96] \\
\hline \multirow[t]{3}{*}{ ATN-161 } & $\begin{array}{l}\text { Small peptide } \\
\text { antagonist }\end{array}$ & Preclinical & $a 5 \beta 1$ & $\begin{array}{l}\text { MDA-MB-231 human breast xenograft and skeletal } \\
\text { metastasis }\end{array}$ & [99] \\
\hline & & Preclinical & $a 5 \beta 1$ & Lewis lung adenocarcinoma model & [98] \\
\hline & & Phase I & $a 5 \beta 1$ & Patients with advanced solid malignancies & {$[106]$} \\
\hline ATN-161 + 5-fluorouracil & $\begin{array}{l}\text { Small peptide antagonist + } \\
\text { chemotherapy }\end{array}$ & Preclinical & $a 5 \beta 1$ & CT26 murine colorectal liver metastasis & {$[100]$} \\
\hline
\end{tabular}

mAb, monoclonal antibody.

have shown that disruption of the $\alpha 2 \beta 1$-integrin enhanced tumor cell migration, intravasation and anchorage-independent growth [92]. Moreover, analysis of gene expression profiling data established a correlation between loss of $\alpha 2 \beta 1$-integrin expression and metastasis and decreased survival in breast cancer patients [92]. Deleting the $\alpha 2$-integrin subunit, hence precluding $\alpha 2 \beta 1$ integrin heterodimer expression, has thus revealed antagonistic effects in Neu-driven mammary cancer progression compared with deleting the $\beta 1$-subunit and thus all of the $\beta 1$ heterodimers. Understanding the role and influence of each specific heterodimer in mammary tumorigenesis might be essential to develop a more selective therapeutic approach. Although this constitutes a major challenge, the diversity of $\beta 1$-integrin heterodimers in mammary tissue still provides great opportunities for drug development [10,94].

For example, strategies developed against the $\alpha 5 \beta 1$ heterodimer, an integrin expressed on the basal surface of myoepithelial mammary ductal cells, led to the development of a rat-anti-mouse blocking antibody able to inhibit the growth of established tumors in multiple xenograft models [95]. Volociximab, another blocking antibody against $\alpha 5 \beta 1$-integrin that is currently in multiple phase II clinical trials, including as monotherapy in patients with platinum-resistant advanced epithelial ovarian cancer or primary peritoneal cancer [96], was found to significantly inhibit tumor growth when administered intravenously in the rabbit VX2 carcinoma model [97]. ATN-161, an integrin-binding peptide inhibitor that is currently in phase II trials in cancer patients, represents another $\alpha 5 \beta 1$ therapeutic strategy [98]. In a
MDA-MB-231 human breast cancer cell xenograft model, treatment with ATN-161 caused a significant decrease in both tumor growth and metastasis [99]. Furthermore, the combination of ATN-161 and fluorouracil reduced colorectal liver metastases and improved survival in mice compared with either therapeutic alone [100]. Other inhibitors targeting $\beta 1$-integrins have been developed, particularly nonpeptide inhibitors of $\alpha 4 \beta 1$-integrin, and are in phase II clinical trials as candidate drugs for asthma, multiple sclerosis, or ulcerative colitis [94]. It would be interesting to test these drugs in preclinical models of breast cancer.

Another attractive aspect of targeting $\beta 1$-integrins comes from the fact that their inhibition can potentiate efficiency of existing treatments (Table 1). By combining the $\beta 1$-integrin blocking antibody AIIB2 and trastuzumab in HER-2-positive cells known to be sensitive to trastuzumab (SKBR-3 and BT-474) or resistant to trastuzumab (JIMT-1), Lesniak and colleagues observed that concomitant inhibition of $\beta 1$-integrin and HER-2 synergistically increased the cytotoxic or antiproliferative effects of trastuzumab and preferentially suppressed the survival or growth of HER-2-positive cells overexpressing $\beta 1$ integrin [67]. Also, AIIB2 has been shown to synergize with ionizing radiation to significantly decrease AKTmediated ionizing radiation resistance of breast cancer cell lines. In vivo, addition of AIIB2 after ionizing radiation significantly enhanced tumor growth inhibition and apoptosis compared with either treatment alone in a breast cancer xenograft model [101,102]. These data provide great expectations of enhanced radiation therapy in breast cancer. 


\section{Conclusions}

Taken together, the above data reveal that $\beta 1$-integrins (as well as some of their signaling partners) may represent attractive therapeutic targets for the treatment of primary breast cancer. The use of transgenic mouse models of breast cancer (that is, MMTV-PyVmT and MMTVactivated ErbB2) has provided direct in vivo evidence for the importance of $\beta 1$-integrins in mammary tumor progression. Notwithstanding, one may have reservations about the models utilized $[4,73]$. Indeed, one limitation of these transgenic mouse models is that expression of the oncogene is driven by a strong viral promoter. Not only does MMTV drive high levels of transgene expression, but it integrates totally randomly into the mouse genome $[79,103]$. The use of the ErbB2 knockin model $[79,104]$, where the Cre-inducible expression of activated ErbB2 is under the transcriptional control of the endogenous ErbB2 promoter, would provide even more representative insights into the role of $\beta 1$-integrin in breast cancer progression. Remarkably, this unique model presents aspects very similar to the human pathology: amplification of erbB2 and histological features of noninvasive ductal carcinoma in situ [73]. Nonetheless, the in vivo data so far collected highlight the crucial role of $\beta 1$-integrin in mammary tumor progression, in particular in its metastatic phase, and are of great clinical interest, given that metastasis still represents the leading cause of death in breast cancer patients.

\section{Abbreviations}

BM, basement membrane; ECM, extracellular matrix; EGFR, epidermal growth factor receptor; ELISA, enzyme-linked immunosorbent assay; FAK, focal adhesion kinase; HER2, human epidermal growth factor receptor 2; MMTV, mouse mammary tumor virus; p130Cas, Crk-associated substrate; PI3K, phosphatidylinositol-3-kinase; PyVmT, polyoma virus middle T antigen.

\section{Competing interests}

The authors declare that they have no competing interests.

\section{Acknowledgements}

The authors apologize for any relevant published work not included due to size limitations. They would like to thank Harvey W Smith for proofreading the manuscript. The present work was supported by grants from the Terry Fox Foundation, the Canadian Institutes of Health Research, the Canadian Cancer Society, the Canadian Breast Cancer Research Alliance, the US Department of Defense Breast Cancer Research Program, and the National Institutes of Health.

Published: 30 November 2011

\section{References}

1. Jemal A, Center MM, DeSantis C, Ward EM: Global patterns of cancer incidence and mortality rates and trends. Cancer Epidemiol Biomarkers Prev 2010, 19:1893-1907.

2. Sadikovic B, Al-Romaih K, Squire JA, Zielenska M: Cause and consequences of genetic and epigenetic alterations in human cancer. Curr Genomics 2008, 9:394-408.

3. Guarneri V, Conte P: Metastatic breast cancer: therapeutic options according to molecular subtypes and prior adjuvant therapy. Oncologist 2009, 14:645-656.

4. Allred DC, Medina D: The relevance of mouse models to understanding the development and progression of human breast cancer. J Mammary Gland Biol Neoplasia 2008, 13:279-288.
5. Brooks SA, Lomax-Browne HJ, Carter TM, Kinch CE, Hall DM: Molecular interactions in cancer cell metastasis. Acta Histochem 2010, 112:3-25.

6. Guo W, Giancotti FG: Integrin signalling during tumour progression. Nat Rev Mol Cell Biol 2004, 5:816-826.

7. Hynes RO: Integrins: bidirectional, allosteric signaling machines. Cell 2002, 110:673-687.

8. Zaidel-Bar R, Itzkovitz S, Ma'ayan A, lyengar R, Geiger B: Functional atlas of the integrin adhesome. Nat Cell Biol 2007, 9:858-867.

9. Legate KR, Wickstrom SA, Fassler R: Genetic and cell biological analysis of integrin outside-in signaling. Genes Dev 2009, 23:397-418.

10. Desgrosellier JS, Cheresh DA: Integrins in cancer: biological implications and therapeutic opportunities. Nat Rev Cancer 2010, 10:9-22.

11. Anthis NJ, Campbell ID: The tail of integrin activation. Trends Biochem Sci 2011, 36:191-198.

12. Luo BH, Carman CV, Springer TA: Structural basis of integrin regulation and signaling. Annu Rev Immunol 2007, 25:619-647.

13. Arnaout MA, Goodman SL, Xiong JP: Structure and mechanics of integrinbased cell adhesion. Curr Opin Cell Biol 2007, 19:495-507.

14. Huveneers $\mathrm{S}$, Danen $\mathrm{EH}$ : Adhesion signaling - crosstalk between integrins, Src and Rho. J Cell Sci 2009, 122(Pt 8):1059-1069.

15. Soung $\mathrm{YH}$, Clifford $J \mathrm{~L}$, Chung J: Crosstalk between integrin and receptor tyrosine kinase signaling in breast carcinoma progression. BMB Rep 2010, 43:311-318.

16. Caswell PT, Vadrevu S, Norman JC: Integrins: masters and slaves of endocytic transport. Nat Rev Mol Cell Biol 2009, 10:843-853.

17. Brakebusch C, Fassler R: Beta1 integrin function in vivo: adhesion, migration and more. Cancer Metastasis Rev 2005, 24:403-411.

18. Taddei I, Faraldo MM, Teuliere J, Deugnier MA, Thiery JP, Glukhova MA: Integrins in mammary gland development and differentiation of mammary epithelium. J Mammary Gland Biol Neoplasia 2003, 8:383-394.

19. Aszodi A, Hunziker EB, Brakebusch C, Fassler R: Beta1 integrins regulate chondrocyte rotation, G1 progression, and cytokinesis. Genes Dev 2003, 17:2465-2479.

20. Burkin DJ, Wallace GQ, Nicol KJ, Kaufman DJ, Kaufman SJ: Enhanced expression of the alpha 7 beta 1 integrin reduces muscular dystrophy and restores viability in dystrophic mice. J Cell Biol 2001, 152:1207-1218.

21. Schwander M, Leu M, Stumm M, Dorchies OM, Ruegg UT, Schittny J, Muller U: $\beta 1$ integrins regulate myoblast fusion and sarcomere assembly. Dev Cell 2003, 4:673-685.

22. Brakebusch C, Grose R, Quondamatteo F, Ramirez A, Jorcano JL, Pirro A, Svensson M, Herken R, Sasaki T, Timpl R, Werner S, Fassler R: Skin and hair follicle integrity is crucially dependent on beta 1 integrin expression on keratinocytes. EMBO J 2000, 19:3990-4003.

23. Belvindrah R, Graus-Porta D, Goebbels S, Nave KA, Muller U: Beta1 integrins in radial glia but not in migrating neurons are essential for the formation of cell layers in the cerebral cortex. J Neurosci 2007, 27:13854-13865.

24. Mettouchi A, Meneguzzi G: Distinct roles of $\beta 1$ integrins during angiogenesis. Eur J Cell Biol 2006, 85:243-247.

25. Anderson R, Fassler R, Georges-Labouesse E, Hynes RO, Bader BL, Kreidberg JA, Schaible K, Heasman J, Wylie C: Mouse primordial germ cells lacking $\beta 1$ integrins enter the germline but fail to migrate normally to the gonads. Development 1999, 126:1655-1664

26. Fassler R, Meyer M: Consequences of lack of beta 1 integrin gene expression in mice. Genes Dev 1995, 9:1896-1908.

27. Stephens LE, Sutherland AE, Klimanskaya IV, Andrieux A, Meneses J, Pedersen RA, Damsky CH: Deletion of beta 1 integrins in mice results in inner cell mass failure and peri-implantation lethality. Genes Dev 1995, 9:1883-1895.

28. Legate KR, Fassler R: Mechanisms that regulate adaptor binding to betaintegrin cytoplasmic tails. J Cell Sci 2009, 122(Pt 2):187-198.

29. Liu S, Calderwood DA, Ginsberg MH: Integrin cytoplasmic domain-binding proteins. J Cell Sci 2000, 113(Pt 20):3563-3571.

30. Regent M, Planus E, Bouin AP, Bouvard D, Brunner M, Faurobert E, MillonFremillon A, Block MR, Albiges-Rizo C: Specificities of beta(1) integrin signaling in the control of cell adhesion and adhesive strength. Eur J Cell Biol 2011, 90:261-269.

31. Mitra SK, Hanson DA, Schlaepfer DD: Focal adhesion kinase: in command and control of cell motility. Nat Rev Mol Cell Bio/ 2005, 6:56-68.

32. Wennerberg K, Armulik A, Sakai T, Karlsson M, Fassler R, Schaefer EM, Mosher $D F$, Johansson S: The cytoplasmic tyrosines of integrin subunit $\beta 1$ are involved in focal adhesion kinase activation. Mol Cell Biol 2000, 20:5758-5765. 
33. Schaller MD, Otey CA, Hildebrand JD, Parsons JT: Focal adhesion kinase and paxillin bind to peptides mimicking beta integrin cytoplasmic domains. J Cell Biol 1995, 130:1181-1187.

34. Brown MC, Turner CE: Paxillin: adapting to change. Physiol Rev 2004, 84:1315-1339

35. Thomas JW, Cooley MA, Broome JM, Salgia R, Griffin JD, Lombardo CR, Schaller MD: The role of focal adhesion kinase binding in the regulation of tyrosine phosphorylation of paxillin. J Biol Chem 1999, 274:36684-36692.

36. Mitra SK, Schlaepfer DD: Integrin-regulated FAK-Src signaling in normal and cancer cells. Curr Opin Cell Biol 2006, 18:516-523.

37. Playford MP, Schaller MD: The interplay between Src and integrins in normal and tumor biology. Oncogene 2004, 23:7928-7946.

38. Mitra SK, Mikolon D, Molina JE, Hsia DA, Hanson DA, Chi A, Lim ST, BernardTrifilo JA, llic D, Stupack DG, Cheresh DA, Schlaepfer DD: Intrinsic FAK activity and Y925 phosphorylation facilitate an angiogenic switch in tumors. Oncogene 2006, 25:5969-5984.

39. Xia H, Nho RS, Kahm J, Kleidon J, Henke CA: Focal adhesion kinase is upstream of phosphatidylinositol 3-kinase/Akt in regulating fibroblast survival in response to contraction of type I collagen matrices via a beta 1 integrin viability signaling pathway. J Biol Chem 2004, 279:33024-33034.

40. Gustavsson A, Yuan M, Fallman M: Temporal dissection of $\beta 1$-integrin signaling indicates a role for p130Cas-Crk in filopodia formation. J Biol Chem 2004, 279:22893-22901.

41. Almeida EA, Ilic D, Han Q, Hauck CR, Jin F, Kawakatsu H, Schlaepfer DD, Damsky CH: Matrix survival signaling: from fibronectin via focal adhesion kinase to c-Jun NH(2)-terminal kinase. J Cell Biol 2000, 149:741-754.

42. Klinowska TC, Soriano JV, Edwards GM, Oliver JM, Valentijn AJ, Montesano R, Streuli CH: Laminin and $\beta 1$ integrins are crucial for normal mammary gland development in the mouse. Dev Biol 1999, 215:13-32

43. Li N, Zhang Y, Naylor MJ, Schatzmann F, Maurer F, Wintermantel T, Schuetz G, Mueller U, Streuli $\mathrm{CH}$, Hynes NE: Beta1 integrins regulate mammary gland proliferation and maintain the integrity of mammary alveoli. EMBO J 2005, 24:1942-1953

44. Naylor MJ, Li N, Cheung J, Lowe ET, Lambert E, Marlow R, Wang P, Schatzmann F, Wintermantel T, Schuetz G, Clarke AR, Mueller U, Hynes NE, Streuli $\mathrm{CH}$ : Ablation of $\beta 1$ integrin in mammary epithelium reveals a key role for integrin in glandular morphogenesis and differentiation. J Cell Biol 2005, 171:717-728.

45. Pontier SM, Muller WJ: Integrins in mammary-stem-cell biology and breastcancer progression - a role in cancer stem cells? J Cell Sci 2009, 122(Pt 2):207-214

46. Taddei I, Deugnier MA, Faraldo MM, Petit V Bouvard D, Medina D, Fassler R, Thiery JP, Glukhova MA: Beta1 integrin deletion from the basal compartment of the mammary epithelium affects stem cells. Nat Cell Biol 2008, 10:716-722

47. Shaw LM: Integrin function in breast carcinoma progression. J Mammary Gland Biol Neoplasia 1999, 4:367-376.

48. Litjens SH, de Pereda JM, Sonnenberg A: Current insights into the formation and breakdown of hemidesmosomes. Trends Cell Biol 2006, 16:376-383.

49. Woodward TL, Mienaltowski AS, Modi RR, Bennett JM, Haslam SZ: Fibronectin and the alpha(5)beta(1) integrin are under developmental and ovarian steroid regulation in the normal mouse mammary gland. Endocrinology 2001, 142:3214-3222.

50. Novaro V, Roskelley CD, Bissell MJ: Collagen-IV and laminin-1 regulate estrogen receptor alpha expression and function in mouse mammary epithelial cells. J Cell Sci 2003, 116(Pt 14):2975-2986.

51. Gardner H, Kreidberg J, Koteliansky V, Jaenisch R: Deletion of integrin alpha 1 by homologous recombination permits normal murine development but gives rise to a specific deficit in cell adhesion. Dev Bio/ 1996 175:301-313.

52. Klinowska TC, Alexander CM, Georges-Labouesse E, Van der Neut R, Kreidberg JA, Jones CJ, Sonnenberg A, Streuli CH: Epithelial development and differentiation in the mammary gland is not dependent on alpha 3 or alpha 6 integrin subunits. Dev Biol 2001, 233:449-467.

53. Chen J, Diacovo TG, Grenache DG, Santoro SA, Zutter MM: The alpha(2) integrin subunit-deficient mouse: a multifaceted phenotype including defects of branching morphogenesis and hemostasis. Am J Pathol 2002, 161:337-344.

54. Lahlou H, Sanquin-Gendreau V, Zuo D, Cardiff RD, McLean GW, Frame MC, Muller WJ: Mammary epithelial-specific disruption of the focal adhesion kinase blocks mammary tumor progression. Proc Natl Acad Sci U S A 2007.
104:20302-20307.

55. White DE, Kurpios NA, Zuo D, Hassell JA, Blaess S, Mueller U, Muller WJ: Targeted disruption of beta1-integrin in a transgenic mouse model of human breast cancer reveals an essential role in mammary tumor induction. Cancer Cell 2004, 6:159-170.

56. Jones $J L$, Critchley DR, Walker RA: Alteration of stromal protein and integrin expression in breast - a marker of premalignant change? J Patho/ 1992, 167:399-406

57. Jonjic N, Lucin K, Krstulja M, Iternicka Z, Mustac E: Expression of beta-1 integrins on tumor cells of invasive ductal breast carcinoma. Pathol Res Pract 1993, 189:979-984.

58. Koukoulis GK, Virtanen I, Korhonen M, Laitinen L, Quaranta V, Gould VE: Immunohistochemical localization of integrins in the normal, hyperplastic, and neoplastic breast. Correlations with their functions as receptors and cell adhesion molecules. Am J Pathol 1991, 139:787-799.

59. Pignatelli M, Cardillo MR, Hanby A, Stamp GW: Integrins and their accessory adhesion molecules in mammary carcinomas: loss of polarization in poorly differentiated tumors. Hum Pathol 1992, 23:1159-1166.

60. Zutter MM, Krigman HR, Santoro SA: Altered integrin expression in adenocarcinoma of the breast. Analysis by in situ hybridization. Am $\lrcorner$ Pathol 1993, 142:1439-1448

61. Berry MG, Gui GP, Wells CA, Carpenter R: Integrin expression and survival in human breast cancer. Eur J Surg Oncol 2004, 30:484-489.

62. Gonzalez MA, Pinder SE, Wencyk PM, Bell JA, Elston CW, Nicholson RI, Robertson JF, Blamey RW, Ellis IO: An immunohistochemical examination of the expression of $\mathrm{E}$-cadherin, $\alpha$ - and $\beta / \gamma$-catenins, and $\alpha 2$ - and $\beta 1$ integrins in invasive breast cancer. J Pathol 1999, 187:523-529.

63. Berry MG, Goode AW, Puddefoot JR, Vinson GP, Carpenter R: Integrin $\beta 1$ mediated invasion of human breast cancer cells: an ex vivo assay for invasiveness. Breast Cancer 2003, 10:214-219.

64. Park CC, Zhang H, Pallavicini M, Gray JW, Baehner F, Park CJ, Bissell MJ: Beta1 integrin inhibitory antibody induces apoptosis of breast cancer cells, inhibits growth, and distinguishes malignant from normal phenotype in three dimensional cultures and in vivo. Cancer Res 2006, 66:1526-1535.

65. Weaver VM, Petersen OW, Wang F, Larabell CA, Briand P, Damsky C, Bissell MJ: Reversion of the malignant phenotype of human breast cells in threedimensional culture and in vivo by integrin blocking antibodies. J Cell Biol 1997, 137:231-245.

66. Yao ES, Zhang H, Chen YY, Lee B, Chew K, Moore D, Park C: Increased $\beta 1$ integrin is associated with decreased survival in invasive breast cancer. Cancer Res 2007, 67:659-664

67. Lesniak D, XuY, Deschenes J, Lai R, Thoms J, Murray D, Gosh S, Mackey JR, Sabri S, Abdulkarim B: Beta1-integrin circumvents the antiproliferative effects of trastuzumab in human epidermal growth factor receptor-2positive breast cancer. Cancer Res 2009, 69:8620-8628.

68. Golubovskaya VM, Kweh FA, Cance WG: Focal adhesion kinase and cancer. Histol Histopathol 2009, 24:503-510

69. Watermann DO, Gabriel B, Jager M, Orlowska-Volk M, Hasenburg A, zur Hausen A, Gitsch G, Stickeler E: Specific induction of pp125 focal adhesion kinase in human breast cancer. Br $J$ Cancer 2005, 93:694-698.

70. Short SM, Yoder BJ, Tarr SM, Prescott NL, Laniauskas S, Coleman KA, DownsKelly E, Pettay JD, Choueiri TK, Crowe JP, Tubbs RR, Budd TG, Hicks DG: The expression of the cytoskeletal focal adhesion protein paxillin in breast cancer correlates with HER2 overexpression and may help predict response to chemotherapy: a retrospective immunohistochemical study. Breast J 2007, 13:130-139.

71. Dorssers LC, Grebenchtchikov N, Brinkman A, Look MP, van Broekhoven SP, de Jong D, Peters HA, Portengen H, Meijer-van Gelder ME, Klijn JG, van Tienoven DT, Geurts-Moespot A, Span PN, Foekens JA, Sweep FC: The prognostic value of BCAR1 in patients with primary breast cancer. Clin Cancer Res 2004, 10(18 Pt 1):6194-6202.

72. Lin EY, Jones JG, Li P, Zhu L, Whitney KD, Muller WJ, Pollard JW: Progression to malignancy in the polyoma middle T oncoprotein mouse breast cancer model provides a reliable model for human diseases. Am J Pathol 2003, 163:2113-2126.

73. Marcotte R, Muller WJ: Signal transduction in transgenic mouse models of human breast cancer - implications for human breast cancer. J Mammary Gland Biol Neoplasia 2008, 13:323-335.

74. Pontier SM, Muller WJ: Integrins in breast cancer dormancy. APMIS 2008, 116:677-684.

75. Luo M, Fan H, Nagy T, Wei H, Wang C, Liu S, Wicha MS, Guan JL: Mammary 
epithelial-specific ablation of the focal adhesion kinase suppresses mammary tumorigenesis by affecting mammary cancer stem/progenitor cells. Cancer Res 2009, 69:466-474

76. Provenzano PP, Inman DR, Eliceiri KW, Beggs HE, Keely PJ: Mammary epithelial-specific disruption of focal adhesion kinase retards tumor formation and metastasis in a transgenic mouse model of human breast cancer. Am J Pathol 2008, 173:1551-1565.

77. Pylayeva Y, Gillen KM, Gerald W, Beggs HE, Reichardt LF, Giancotti FG: Rasand PI3K-dependent breast tumorigenesis in mice and humans requires focal adhesion kinase signaling. J Clin Invest 2009, 119:252-266.

78. Eccles SA: The role of c-erbB-2/HER2/neu in breast cancer progression and metastasis. J Mammary Gland Biol Neoplasia 2001, 6:393-406.

79. Ursini-Siegel J, Schade B, Cardiff RD, Muller WJ: Insights from transgenic mouse models of ERBB2-induced breast cancer. Nat Rev Cancer 2007, 7:389-397.

80. Huck L, Pontier SM, Zuo DM, Muller WJ: Beta1-integrin is dispensable for the induction of ErbB2 mammary tumors but plays a critical role in the metastatic phase of tumor progression. Proc Natl Acad Sci U S A 2010, 107:15559-15564

81. Ursini-Siegel J, Hardy WR, Zuo D, Lam SH, Sanguin-Gendreau V, Cardiff RD, Pawson T, Muller WJ: ShcA signalling is essential for tumour progression in mouse models of human breast cancer. EMBO J2008, 27:910-920.

82. Moro L, Dolce L, Cabodi S, Bergatto E, Boeri Erba E, Smeriglio M, Turco E, Retta SF, Giuffrida MG, Venturino M, Godovac-Zimmermann J, Conti A, Schaefer E, Beguinot L, Tacchetti C, Gaggini P, Silengo L, Tarone G, Defilippi P: Integrininduced epidermal growth factor (EGF) receptor activation requires c-Src and p130Cas and leads to phosphorylation of specific EGF receptor tyrosines. J Biol Chem 2002, 277:9405-9414.

83. Caswell PT, Chan M, Lindsay AJ, McCaffrey MW, Boettiger D, Norman JC: Rab-coupling protein coordinates recycling of a5 $\beta 1$ integrin and EGFR1 to promote cell migration in 3D microenvironments. J Cell Biol 2008, 183:143-155.

84. Liu Y, Pixley R, Fusaro M, Godoy G, Kim E, Bromberg ME, Colman RW: Cleaved high-molecular-weight kininogen and its domain 5 inhibit migration and invasion of human prostate cancer cells through the epidermal growth factor receptor pathway. Oncogene 2009, 28:2756-2765.

85. Tagliabue E, Ghirelli C, Squicciarini P, Aiello P, Colnaghi MI, Menard S: Prognostic value of alpha 6 beta 4 integrin expression in breast carcinomas is affected by laminin production from tumor cells. Clin Cancer Res 1998, 4:407-410

86. Chung J, Mercurio AM: Contributions of the alpha6 integrins to breast carcinoma survival and progression. Mol Cells 2004, 17:203-209.

87. Gilcrease MZ, Zhou X, LuX, Woodward WA, Hall BE, Morrissey PJ: Alpha6beta4 integrin crosslinking induces EGFR clustering and promotes EGF-mediated Rho activation in breast cancer. J Exp Clin Cancer Res 2009, 28:67-76.

88. Guo W, Pylayeva Y, Pepe A, Yoshioka T, Muller WJ, Inghirami G, Giancotti FG: Beta 4 integrin amplifies ErbB2 signaling to promote mammary tumorigenesis. Cell 2006, 126:489-502.

89. Pontier SM, Huck L, White DE, Rayment J, Sanguin-Gendreau V, Hennessy B, Zuo D, St-Arnaud R, Mills GB, Dedhar S, Marshall CJ, Muller WJ: Integrinlinked kinase has a critical role in ErbB2 mammary tumor progression: implications for human breast cancer. Oncogene 2010, 29:3374-3385.

90. Cabodi S, Tinnirello A, Di Stefano P, Bisaro B, Ambrosino E, Castellano I, Sapino A, Arisio R, Cavallo F, Forni G, Glukhova M, Silengo L, Altruda F, Turco E, Tarone $G$, Defilippi P: p130Cas as a new regulator of mammary epithelial cell proliferation, survival, and HER2-neu oncogene-dependent breast tumorigenesis. Cancer Res 2006, 66:4672-4680.

91. Taverna D, Crowley D, Connolly M, Bronson RT, Hynes RO: A direct test of potential roles for $\beta 3$ and $\beta 5$ integrins in growth and metastasis of murine mammary carcinomas. Cancer Res 2005, 65:10324-10329.

92. Ramirez NE, Zhang Z, Madamanchi A, Boyd KL, O'Rear LD, Nashabi A, Li Z, Dupont WD, Zijlstra A, Zutter MM: The a $\beta$ integrin is a metastasis suppressor in mouse models and human cancer. J Clin Invest 2011, 121:226-237.

93. Yoshimura K, Meckel KF, Laird LS, Chia CY, Park JJ, Olino KL, Tsunedomi R, Harada T, lizuka N, Hazama S, Kato Y, Keller JW, Thompson JM, Chang F, Romer LH, Jain A, lacobuzio-Donahue C, Oka M, Pardoll DM, Schulick RD: Integrin a2 mediates selective metastasis to the liver. Cancer Res 2009, 69:7320-7328.

94. Cox D, Brennan M, Moran N: Integrins as therapeutic targets: lessons and opportunities. Nat Rev Drug Discov 2010, 9:804-820.

95. Bhaskar V, Zhang D, Fox M, Seto P, Wong MH, Wales PE, Powers D, Chao DT, Dubridge RB, Ramakrishnan V: A function blocking anti-mouse integrin a5 $\beta 1$ antibody inhibits angiogenesis and impedes tumor growth in vivo. J Trans/ Med 2007, 5:61-71.

96. Bell-McGuinn KM, Matthews CM, Ho SN, Barve M, Gilbert L, Penson RT, Lengyel E, Palaparthy R, Gilder K, Vassos A, McAuliffe W, Weymer S, Barton J, Schilder RJ: A phase II, single-arm study of the anti-a $5 \beta 1$ integrin antibody volociximab as monotherapy in patients with platinum-resistant advanced epithelial ovarian or primary peritoneal cancer. Gynecol Oncol 2011, 121:273-279

97. Bhaskar V, Fox M, Breinberg D, Wong MH, Wales PE, Rhodes S, DuBridge RB, Ramakrishnan V: Volociximab, a chimeric integrin a $5 \beta 1$ antibody, inhibits the growth of $\mathrm{VX2}$ tumors in rabbits. Invest New Drugs 2008, 26:7-12.

98. Donate F, Parry GC, Shaked Y, Hensley H, Guan X, Beck I, Tel-Tsur Z, Plunkett ML, Manuia M, Shaw DE, Kerbel RS, Mazar AP: Pharmacology of the novel antiangiogenic peptide ATN-161 (Ac-PHSCN-NH2): observation of a Ushaped dose-response curve in several preclinical models of angiogenesis and tumor growth. Clin Cancer Res 2008, 14:2137-2144.

99. Khalili P, Arakelian A, Chen G, Plunkett ML, Beck I, Parry GC, Donate F, Shaw DE, Mazar AP, Rabbani SA: A non-RGD-based integrin binding peptide (ATN-161) blocks breast cancer growth and metastasis in vivo. Mol Cancer Ther 2006, 5:2271-2280.

100. Stoeltzing O, Liu W, Reinmuth N, Fan F, Parry GC, Parikh AA, McCarty MF, Bucana CD, Mazar AP, Ellis $L M$ : Inhibition of integrin a $5 \beta 1$ function with a small peptide (ATN-161) plus continuous 5-FU infusion reduces colorectal liver metastases and improves survival in mice. Int J Cancer 2003, 104:496-503.

101. Nam JM, Chung Y, Hsu HC, Park CC: Beta1 integrin targeting to enhance radiation therapy. Int J Radiat Biol 2009, 85:923-928.

102. Park CC, Zhang HJ, Yao ES, Park CJ, Bissell MJ: Beta1 integrin inhibition dramatically enhances radiotherapy efficacy in human breast cancer xenografts. Cancer Res 2008, 68:4398-4405.

103. Faschinger A, Rouault F, Sollner J, Lukas A, Salmons B, Gunzburg WH, Indik S: Mouse mammary tumor virus integration site selection in human and mouse genomes. J Virol 2008, 82:1360-1367.

104. Andrechek ER, Hardy WR, Siegel PM, Rudnicki MA, Cardiff RD, Muller WJ: Amplification of the neu/erbB-2 oncogene in a mouse model of mammary tumorigenesis. Proc Natl Acad Sci U S A 2000, 97:3444-3449.

105. Ricart AD, Tolcher AW, Liu G, Holen K, Schwartz G, Albertini M, Weiss G, Yazji S, $\mathrm{Ng} \mathrm{C}$, Wilding G: Volociximab, a chimeric monoclonal antibody that specifically binds a 531 integrin: a phase I, pharmacokinetic, and biological correlative study. Clin Cancer Res 2008, 14:7924-7929.

106. Cianfrocca ME, Kimmel KA, Gallo J, Cardoso T, Brown MM, Hudes G, Lewis N, Weiner L, Lam GN, Brown SC, Shaw DE, Mazar AP, Cohen RB: Phase 1 trial of the antiangiogenic peptide ATN-161 (Ac-PHSCN-NH(2)), a beta integrin antagonist, in patients with solid tumours. Br J Cancer 2006, 94:1621-1626.

\section{doi:10.1186/bcr2905}

Cite this article as: Lahlou $H$, Muller WJ: $\beta 1$-integrins signaling and

mammary tumor progression in transgenic mouse models: implications for human breast cancer. Breast Cancer Research 2011, 13:229. 